\title{
Growth and Characterization of Nocardiophages for Nocardia canicruria and Nocardia erythropolis Mating Types
}

\author{
By G. H. BROWNELL AND J. N. ADAMS \\ Department of Microbiology, School of Medicine, \\ University of South Dakota, Vermillion \\ AND S. G. BRADLEY \\ Department of Microbiology, University of Minnesota, Minneapolis
}

(Accepted for publication 20 December 1966)

\begin{abstract}
SUMMARY
Two nocardiophages were isolated from soil samples: one, called $\phi \mathrm{C}$, was specific for the Nocardia canicruria mating type; the other, called $\phi \mathrm{EC}$, proliferated in $N$. canicruria and $N$. erythropolis mating types. Inactivation of phage $\phi \mathrm{C}$ was rapid in $\mathrm{NaCl}$ solutions, with chloroform, $0.3 \%$ hydrogen peroxide and $30 \%(\mathrm{v} / \mathrm{v})$ ethanol in water. Phage $\phi \mathrm{EC}$ behaved similarly but was less labile in $\mathrm{NaCl}$ solutions. Both phages were resistant to diethyl ether. Phage $\phi \mathrm{C}$ could be propagated to titres of $10^{10}$ plaque-forming units $/ \mathrm{ml}$. on a medium containing peptone, yeast extract and calcium nitrate; the highest observed titres of phage $\phi \mathrm{EC}$ were also produced in this medium. A chemically defined medium for proliferation of phage $\phi \mathrm{C}$ consisted of inorganic salts, valine, isoleucine, leucine, nicotinamide, glycerol. Other variables which affected the growth of these phages were the amount of phage and host inocula and the age of the host before infection. Phage $\phi \mathrm{C}$ was distinct from other nocardiophages in its ability to attach quickly and efficiently to its host; $95 \%$ of the phage attached, and attachment was time and temperature dependent. Attachment of phage $\phi \mathrm{EC}$ was slow and inefficient, reaching only $34 \%$. The latent period for phage $\phi \mathrm{C}$ was about $25 \mathrm{~min}$., the increase period was $35 \mathrm{~min}$. and the burst size about 60 particles/infective centre. The latent period of phage $\phi \mathrm{EC}$ was $180 \mathrm{~min}$. and the burst size about 20 particles. Both these nocardiophages possessed the typical actinophage morphology.
\end{abstract}

\section{INTRODUCTION}

Genetic recombination between nocardias of heterologous origin has been demonstrated (Adams, 1964). In general, substrains derived from Nocardia erythropolis do not recombine with each other nor will substrains derived from $N$. canicruria, but 'interspecific' combinations are fertile. These observations indicate a mating factor(s) governing compatibility in nocardial recombination. In further investigations of hereditary phenomena in nocardias, characters have been sought for use in the development of linkage maps. Specific phage-resistance characters are deemed appropriate for such purposes.

Two nocardiophages were isolated from soil. One (phage $\phi C$ ) specifically infected the $N$. canicruria mating type while the second (phage $\phi \mathrm{EC}$ ) infected both the $N$. canicruria and $N$. erythropolis mating types. Although mating-type specific phages have been described for Escherichia coli (Loeb, 1960; Dettori, Maccacaro \& Piccinin, 
1961), they are largely unknown for other bacterial systems. To exploit nocardiophages as genetic markers and to ascertain their exact relationships to mating type, it has been necessary to grow and characterize them. In this report, the conditions necessary for propagating and assaying two nocardiophages are defined, thereby allowing for their further characterization. Special attention has been given phage $\phi \mathrm{C}$ because of its potential application in studies of compatibility phenomena in the nocardias.

\section{METHODS}

Cultures. The hosts used were Nocardia canicruria strain 3 (Adams, 1964) and $N$. canicruria strain 57 (Anderson \& Bradley, 1961). These strains were originally designated Jensenia canicruria (Bisset \& Moore, 1950). Nocardia erythropolis strain 2 (Adams, 1964) was also used. Stock cultures were maintained on nutrient agar (Difco) or on peptone + yeast extract (Difco) medium (PY) composed of $0.5 \%(\mathrm{w} / \mathrm{v})$ peptone and $0.3 \%(\mathrm{w} / \mathrm{v})$ yeast extract solidified, when necessary, with $1.5 \%(\mathrm{w} / \mathrm{v})$ agar. Cultures were maintained at $30^{\circ}$.

Plaque assay medium and phage propagation medium. The plaque-forming capacities of lysates containing phage $\phi \mathrm{C}$ or phage $\phi \mathrm{EC}$ were determined by the conventional soft-agar overlay technique (Jones \& Bradley, 1962) with nutrient agar or PY agar as the nutrient. In some tests, the assay media were supplemented with $0.01 \mathrm{M}-\mathrm{NaCl}$, $0.1 \mathrm{M}-\mathrm{NaCl}$, or $0.01 \mathrm{M}-\mathrm{Ca}\left(\mathrm{NO}_{3}\right)_{2}$. Plaque numbers were not appreciably affected by supplementation and PY agar containing $0.01 \mathrm{M}-\mathrm{Ca}\left(\mathrm{NO}_{3}\right)_{2}$ was arbitrarily chosen as the routine plaque assay medium. To determine the effects of salts on nocardiophage growth, nutrient broth or PY broth supplemented with $\mathrm{NaCl}$ or $\mathrm{Ca}\left(\mathrm{NO}_{3}\right)_{2}$ was inoculated with Nocardia canicruria to give an extinction of 0.1 at $620 \mathrm{~m} \mu$. After incubation for $2 \mathrm{hr}$ at $30^{\circ}$, phage $\phi \mathrm{C}$ or phage $\phi \mathrm{EC}$ was added to a final concentration of $1 \times 10^{7}$ plaque-forming units (p.f.u.)/ml. The phage-infected cultures were assayed for increase in p.f.u. values after incubation for 4 or $12 \mathrm{hr}$.

Determination of nocardiophage stability. To discover suitable diluents for phages $\phi \mathrm{C}$ and $\phi \mathrm{EC}, 0.1 \mathrm{ml}$. samples of stock phage preparations were added to various diluents and maintained at $25^{\circ}$ for $2 \mathrm{hr}$. The stability of phages $\phi \mathrm{C}$ and $\phi \mathrm{EC}$ to materials commonly lethal for other bacteriophages was tested by incubating mixtures of nocardiophage with different reagents at $25^{\circ}$ for $2 \mathrm{hr}$.

Determination of factors which affect nocardiophage attachment. Several factors were tested for their effect upon attachment of nocardiophage. A $2 \mathrm{hr}$ culture of Nocardia canicruria was harvested and resuspended in different media to an extinction of 0.4 at $620 \mathrm{~m} \mu$. Phage was added and $5 \mathrm{~min}$. later the mixture was sampled, diluted into 4 volumes of broth, centrifuged and the titre of the supernatant fluid determined. Attachment was expressed as the ratio of free phage particles present in the supernatant fluid to the total phage count. Alternatively, a sample of the whole culture was shaken with an equal volume of diethyl ether and the titre of the aqueous layer measured. In this case, attachment was expressed as the ratio of the number of phage particles present in the aqueous phase of the ether-treated culture to that of the untreated sample. Another method used to measure phage to host attachment involved the addition of specific antiphage serum (Bradley, Papermaster, Watson \& Good, 1961). Phage able to form plaques after the addition of antiserum was considered to be attached to the host. 
Effect of host age and inoculum sizes on phage propagation. The effect of host age on phage propagation was tested by adding suitable concentrations of phage to the host which had been incubated for various times. Twelve hr after the addition of phage, the phage titre was determined. The effect of the size of the phage inoculum on propagation was examined by mixing phage inocula at different concentrations with a standard host concentration and measuring the p.f.u. after incubation for $3 \mathrm{hr}$ and $24 \mathrm{hr}$. The effect of the host-inoculum size on phage proliferation was determined by varying the host inoculum concentration and assaying plaque numbers.

Propagation dynamics. A $2 \mathrm{hr}$ host culture having an extinction of 0.1 at $620 \mathrm{~m} \mu$ in PY broth supplemented with $0.01 \mathrm{M}-\mathrm{Ca}\left(\mathrm{NO}_{3}\right)_{2}$ was inoculated with phage $\phi \mathrm{C}$, $5 \times 10^{8}$ p.f.u. $/ \mathrm{ml}$. or phage $\phi \mathrm{EC}, 1.9 \times 10^{6}$ p.f.u. $/ \mathrm{ml}$. At intervals, after allowing $10 \mathrm{~min}$. for adsorption, samples were removed, diluted in fresh medium and assayed for plaque numbers.

Minimal medium. A $3 \mathrm{hr}$ culture of Nocardia canicruria was harvested and resuspended in $0.001 \mathrm{M}-\mathrm{Ca}\left(\mathrm{NO}_{3}\right)_{2}(\mathrm{pH} 7)$ to an extinction of 0.2 at $620 \mathrm{~m} \mu$. To this suspension various supplements were added and phage $\phi \mathrm{C}$ added to obtain $2.5 \times 10^{6}$ p.f.u. $/ \mathrm{ml}$. in the mixture. After incubation for $3 \mathrm{hr}$ at $30^{\circ}$, the mixtures were assayed for plaque numbers.

Host range. The host ranges of phages $\phi \mathrm{C}$ and $\phi \mathrm{EC}$ were determined using methods described previously (Anderson \& Bradley, 1961). The host ranges of $\phi \mathrm{C}$ and $\phi \mathrm{EC}$ were compared to the host range of phage MJP1. This phage, MJP1, was isolated on Nocardia canicruria and its host range previously described (Anderson \& Bradley, 1961).

Morphology. The structural features of phages $\phi \mathrm{C}$ and $\phi \mathrm{EC}$ were determined by examining negatively-stained preparations with a Siemen's electron microscope according to the methods of Painter \& Bradley (1965).

\section{RESULTS}

Although the nutrient and salt composition of the plaque assay medium did not markedly affect the titres of phages $\phi \mathrm{C}$ and $\phi \mathrm{EC}$, the composition of the propagation medium was critical. Peptone + yeast extract broth was the best routine nutrient source (Table 1). The addition of $\mathrm{Ca}\left(\mathrm{NO}_{3}\right)_{2}$ stimulated phage production but $0.1 \mathrm{M}$ $\mathrm{NaCl}$ was deleterious. The highest routine phage titres were obtained in PY broth supplemented with $0.01 \mathrm{M}-\mathrm{Ca}\left(\mathrm{NO}_{3}\right)_{2}$.

Phage $\phi \mathrm{C}$ was rapidly inactivated in many salt solutions (Table 2); it was susceptible to $\mathrm{M}-\mathrm{NaCl}$, but was stable for $2 \mathrm{hr}$ at $25^{\circ}$ in $0.01 \mathrm{M}-\mathrm{Ca}\left(\mathrm{NO}_{3}\right)_{2}, \mathrm{MgSO}_{4}$ or tris buffer, and in nutrient broth or PY broth at pH 7. Phage $\phi \mathrm{EC}$ followed the stability pattern of phage $\phi \mathrm{C}$ except that $\phi \mathrm{EC}$ was somewhat more stable in $\mathrm{NaCl}$ solutions.

The two phages were similar in their patterns of resistance to deleterious agents (Table 3). Chloroform and thymol (frequently used to render phage lysates free from living bacteria) decreased the titre of phage $\phi \mathrm{C} 10,000$-fold; chloroform was somewhat less lethal to phage $\phi \mathrm{EC}$, decreasing the titre only 100 -fold. Both phages were rapidly inactivated by ultraviolet irradiation. 
Table 1. Complex medium for propagation of nocardiophages $\phi C$ and $\phi E C$

Nocardia canicruria, at an extinction of $0 \cdot 1$ at $620 \mathrm{~m} \mu$, was incubated for $2 \mathrm{hr}$ at $30^{\circ}$. After host incubation, phages $\phi \mathrm{C}$ or $\phi \mathrm{EC}$ were added to give a final phage concentration of $10^{7}$ p.f.u./ml. After 4 or $12 \mathrm{hr}$ further incubation, plaque numbers were determined.

\begin{tabular}{|c|c|c|c|c|}
\hline \multirow[b]{2}{*}{ Medium } & \multirow[b]{2}{*}{ Supplement } & \multicolumn{2}{|c|}{$\phi \mathrm{C}$ (p.f.u./ml.) } & \multirow{2}{*}{$\begin{array}{c}\phi \mathrm{EC} \\
\text { (p.f.u./ml.) } \\
12 \mathrm{hr}\end{array}$} \\
\hline & & $4 \mathrm{hr}$ & $12 \mathrm{hr}$ & \\
\hline Nutrient broth & \begin{tabular}{l}
$\stackrel{-}{0.1 \mathrm{M}-\mathrm{NaCl}}$ \\
$0.01 \mathrm{M}-\mathrm{NaCl}$ \\
$0.01 \mathrm{M}-\mathrm{Ca}\left(\mathrm{NO}_{3}\right)_{2}$ \\
$0.001 \mathrm{M}-\mathrm{Ca}\left(\mathrm{NO}_{3}\right)_{2}$ \\
\multicolumn{2}{c}{}
\end{tabular} & $\begin{array}{l}2.0 \times 10^{7} \\
<1 \times 10^{5} \\
1.8 \times 10^{7} \\
3.5 \times 10^{9} \\
3.9 \times 10^{9} \\
4.4 \times 10^{8}\end{array}$ & $\begin{array}{l}3.3 \times 10^{8} \\
<1 \times 10^{5} \\
4.4 \times 10^{8} \\
5 \cdot 3 \times 10^{9} \\
6.4 \times 10^{9} \\
5 \cdot 1 \times 10^{9}\end{array}$ & $\begin{array}{l}2.0 \times 10^{9} \\
3.0 \times 10^{3} \\
3.0 \times 10^{6} \\
1.8 \times 10^{8} \\
6.9 \times 10^{9} \\
2.3 \times 10^{9}\end{array}$ \\
\hline PY broth & $\begin{array}{l}0.1 \mathrm{M}-\mathrm{NaCl} \\
0.01 \mathrm{M}-\mathrm{NaCl} \\
0.01 \mathrm{M}-\mathrm{Ca}\left(\mathrm{NO}_{3}\right)_{2} \\
0.001 \mathrm{M}-\mathrm{Ca}\left(\mathrm{NO}_{3}\right)_{2}\end{array}$ & $\begin{array}{l}<1 \times 10^{5} \\
4.7 \times 10^{8} \\
8.2 \times 10^{9} \\
1.6 \times 10^{10}\end{array}$ & $\begin{array}{l}<1 \times 10^{5} \\
3.9 \times 10^{9} \\
1.6 \times 10^{10} \\
9.0 \times 10^{9}\end{array}$ & $\begin{array}{l}1.0 \times 10^{4} \\
9.0 \times 10^{7} \\
3.3 \times 10^{9} \\
2.4 \times 10^{9}\end{array}$ \\
\hline
\end{tabular}

Table 2. Diluents for nocardiophages $\phi C$ and $\phi E C$

A $0.1 \mathrm{ml}$. sample of stock preparations of phages $\phi \mathrm{C}$ or $\phi \mathrm{EC}$ was added to $10 \mathrm{ml}$. of the diluent to be tested. All solutions were previously adjusted to $\mathrm{pH} 7 \cdot 0$. After $2 \mathrm{hr}$ incubation at $25^{\circ}$, the diluent-phage mixtures were assayed for viable phage.

$\begin{array}{lrr} & \text { Phage } \phi \mathrm{C} & \text { Phage } \phi \mathrm{EC} \\ \text { Diluent } & \text { (p.f.u./ml.) } & \text { (p.f.u./ml.) }\end{array}$

Deionized water

$\mathrm{NaCl}(0.001$ to $0.1 \mathrm{M})$

$\mathrm{NaCl}(\mathrm{M})$

PY broth

Nutrient broth

$\mathrm{MgSO}_{4}(0.001-0.01 \mathrm{M})$

$\mathrm{Ca}\left(\mathrm{NO}_{3}\right)_{2}(0.001-0.01 \mathrm{M})$

$\mathrm{KH}_{2} \mathrm{PO}_{4}+\mathrm{K}_{2} \mathrm{HPO}_{4}(0 \cdot 1 \mathrm{M})$

$\mathrm{KH}_{2} \mathrm{PO}_{4}+\mathrm{K}_{2} \mathrm{HPO}_{4}(0.01 \mathrm{M})$

Tris (0.01 M)

$0.01 \mathrm{M}$-tris in $0.001 \mathrm{M}-\mathrm{Ca}\left(\mathrm{NO}_{3}\right)_{2}$

$0.1 \mathrm{~m}-\mathrm{NaCl}+0.001 \mathrm{~m}-\mathrm{Ca}\left(\mathrm{NO}_{3}\right)_{2}$
$9.9 \times 10^{5}$

$8.6 \times 10^{5}$

$1.0 \times 10^{2}$

$2 \cdot 3 \times 10^{8 *}$

$3.3 \times 10^{6 *}$

$2 \cdot 7 \times 10^{6 *}$

$2.4 \times 10^{6 *}$

$5 \cdot 1 \times 10^{3}$

$5.3 \times 10^{5}$

$2.9 \times 10^{8 *}$

$2.5 \times 10^{6 *}$

$2.6 \times 10^{6 *}$

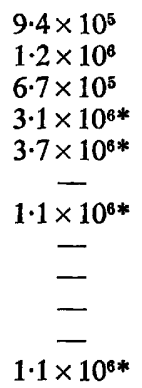

$9.4 \times 10^{5}$

$1.2 \times 10^{6}$

$3 \cdot 1 \times 10^{6 *}$

$3.7 \times 10^{6 *}$

$1.1 \times 10^{6 *}$

$1 \cdot 1 \times 10^{6 *}$

* Satisfactory diluent. - $\quad$, Not done.

\section{Nocardiophage attachment}

Attachment of phage $\phi \mathrm{C}$ was markedly affected by medium composition (Table 4). When water was used as the attachment medium, only $5 \%$ of phage $\phi \mathrm{C}$ particles were effectively attached; the addition of $0.01 \mathrm{M}-\mathrm{Ca}^{2+}$ to PY broth facilitated its attachment. Other media tested were less satisfactory for attachment.

Three methods were used to determine attachment (Table 5). The methods based on the use of antisera or ether sensitivity were equally useful, and indicated slightly greater degrees of attachment than did the centrifugation method.

Attachment of phage $\phi \mathrm{C}$ was retarded at $5^{\circ}$ (Table 6). The best attachment of phage $\phi \mathrm{C}$ was at the highest temperature tested $\left(37^{\circ}\right)$. In contrast, phage $\phi \mathrm{EC}$ attached inefficiently; for example, after $30 \mathrm{~min}$. incubation at $30^{\circ}$ in PY broth containing $0.01 \mathrm{M}-\mathrm{Ca}^{2+}$, phage $\phi \mathrm{C}$ attached with an efficiency of $95 \%$, whereas phage $\phi \mathrm{EC}$ attached with an efficiency of $34 \%$. 


\section{Table 3. Effects of chemical and physical agents on nocardiophages $\phi C$ and $\phi E C$}

To determine the effects of physical treatments, PY broth grown preparations of phages $\phi \mathrm{C}$ or $\phi \mathrm{EC}$ were diluted 1 to 10 in PY broth. A $0.1 \mathrm{ml}$. sample was added to $10 \mathrm{ml}$. PY broth, the physical treatment applied, and viable phage numbers were estimated immediately after the treatment. A similarly diluted but untreated PY broth preparation served as a control. To determine the effects of the chemical agents, PY broth grown preparations of the phages were diluted 1 to 10 in water. A $0 \cdot 1 \mathrm{ml}$. sample of the dilution was added to $10 \mathrm{ml}$. of the reagent to be tested at the specified concentration in water. After $2 \mathrm{hr}$ incubation at $25^{\circ}$, the mixtures were assayed for phage numbers. Nocardia canicruria was used as the host in all cases.

\section{Treatment}

Untreated control

Chloroform*

Thymol $(0 \cdot 1 \mathrm{~g} . / \mathrm{added}$ to $10 \mathrm{ml}$. water $)$

Diethyl ether $\dagger$

Hydrogen peroxide ( $3 \%, v / v$, in water)

Hydrogen peroxide $(0.3 \%, v / v$, in water)

Mercaptoethanol ( $1.5 \mathrm{M}$ in water)

Mercaptoethanol $(0.15 \mathrm{M}$ in water)

Ethanol $(30 \%, v / v$, in water)

Freezing

$45^{\circ}$ for $15 \mathrm{~min}$.

$56^{\circ}$ for $15 \mathrm{~min}$.

Ultrasonic treatment $(20 \mathrm{kc} . / \mathrm{sec}$.) for $60 \mathrm{sec}$.

French press (4000 lb./sq.in.)

Ultraviolet irradiation for $\left\{\begin{array}{r}30 \mathrm{sec} . \\ 90 \mathrm{sec} . \\ 150 \mathrm{sec} . \\ 210 \mathrm{sec} .\end{array}\right.$

$\begin{array}{cc}\begin{array}{c}\text { Phage } \phi \mathrm{C} \\ \text { (p.f.u./ml.) }\end{array} & \begin{array}{c}\text { Phage } \phi \mathrm{EC} \\ \text { (p.f.u./ml.) }\end{array} \\ 2.7 \times 10^{8} & 3.7 \times 10^{8} \\ 1.2 \times 10^{4} & 1.8 \times 10^{4} \\ 1.0 \times 10^{3} & - \\ 1.6 \times 10^{8} & 3.2 \times 10^{8} \\ <1 \times 10^{3} & <1 \times 10^{3} \\ 1.6 \times 10^{4} & 1.5 \times 10^{3} \\ 9.0 \times 10^{4} & 5.0 \times 10^{5} \\ 9.4 \times 10^{7} & 1.0 \times 10^{6} \\ 1.0 \times 10^{3} & <1 \times 10^{3} \\ 2.7 \times 10^{8} & 3.1 \times 10^{8} \\ 1.7 \times 10^{7} & 4.2 \times 10^{4} \\ 8.0 \times 10^{3} & 1.0 \times 10^{3} \\ 2.4 \times 10^{6} & - \\ 1.7 \times 10^{6} & - \\ 2.2 \times 10^{6} & 1.0 \times 10^{4} \\ 1.3 \times 10^{5} & 1.7 \times 10^{3} \\ 2.3 \times 10^{4} & 4.1 \times 10^{2} \\ 2.3 \times 10^{2} & <10^{1}\end{array}$

* Biphasic: 1 vol. chloroform to 2 vol, water. + Biphasic: 1 vol. ether to 3 vol. water. - , Not done.

\section{Table 4. Total attachment of nocardiophage $\phi C$ to washed Nocardia canicruria organisms}

A $2 \mathrm{hr}$ culture of Nocardia canicruria was harvested and resuspended in the indicated media to an extinction of 0.4 at $620 \mathrm{~m} \mu$. Phage was added and after $5 \mathrm{~min}$. to allow for attachment, the mixture was sampled, diluted into 4 vol. of broth, centrifuged and the viable titre of the supernatant fluid was assayed. Alternatively, a whole culture and a sample were shaken with an equal volume of diethyl ether and the phage titre of the aqueous layer was determined.

Attachment medium

\section{Water}

$0 \cdot 1 \mathrm{M}-\mathrm{NaCl}$

Nutrient broth

$0.001 \mathrm{M}-\mathrm{Ca}\left(\mathrm{NO}_{3}\right)_{2}$

$0.01 \mathrm{M}-\mathrm{Ca}\left(\mathrm{NO}_{3}\right)_{2}$

PY broth

PY broth $+0.01 \mathrm{M}-\mathrm{Ca}\left(\mathrm{NO}_{3}\right)_{2}$

$0.1 \mathrm{M}-\mathrm{NaCl}+0.1 \mathrm{M}-\mathrm{Ca}\left(\mathrm{NO}_{3}\right)_{2}$

$\overbrace{\begin{array}{c}\text { Total } \\ \text { phage } \phi \mathrm{C}\end{array} \quad \begin{array}{c}\text { free } \\ \text { phage } \phi \mathrm{C}\end{array}}^{\text {Titre } \times 10^{-3}} \begin{gathered}\% \\ \text { attached }\end{gathered} \begin{gathered}\% \text { ether- } \\ \text { sensitive }\end{gathered}$

339

96

295

255

281

268

248

170
321

50

138

108

101

115

24

88

$\begin{array}{rr}5 & 11 \\ 48 & 50 \\ 53 & 62 \\ 58 & 63 \\ 64 & 63 \\ 57 & 68 \\ 90 & 93 \\ 48 & 56\end{array}$




\section{Table 5. Comparison of three criteria for measuring attachment of nocardiophage $\phi C$ to Nocardia canicruria cells}

A $2 \mathrm{hr}$ culture of Nocardia canicruria was harvested and resuspended in the indicated media to an extinction of 0.4 at $620 \mathrm{~m} \mu$. Phage $\phi \mathrm{C}$ was added to a concentration of $1.9 \times$ $10^{7}$ p.f.u./ml. After $10 \mathrm{~min}$., attachment was determined by the indicated criteria.

\begin{tabular}{|c|c|c|}
\hline & \multicolumn{2}{|c|}{ Attachment medium } \\
\hline \multirow[t]{2}{*}{ Attachment index } & $0.003 \mathrm{M}-\mathrm{Ca}\left(\mathrm{NO}_{3}\right)_{2}$ & $\begin{array}{l}\text { Peptone }+ \text { yeast } \\
\text { extract medium }+ \\
0.01 \mathrm{M}-\mathrm{Ca}\left(\mathrm{NC}_{3}\right)_{2}\end{array}$ \\
\hline & \multicolumn{2}{|c|}{$\%$ phage attached in } \\
\hline Ether sensitivity & $88 \cdot 5$ & $99 \cdot 3$ \\
\hline Antiserum resistant & $92 \cdot 1$ & 100 \\
\hline Free phage & $80 \cdot 6$ & $92 \cdot 4$ \\
\hline
\end{tabular}

Table 6. Effects of time and temperature on attachment of nocardiophage $\phi C$ to Nocardia canicruria

A culture was equilibrated to the indicated temperature and phage $\phi \mathrm{C}$ added to a final concentration of $3.3 \times 10^{6}$ p.f.u. $/ \mathrm{ml}$. At the indicated times, $1 \mathrm{ml}$. samples were mixed with $1 \mathrm{ml}$. of diethyl ether; the aqueous layer was assayed for viable phage.

$\begin{array}{cccc}\text { Time } & \overbrace{5^{\circ}}^{\text {Free phage (temperature variable) }} \\ \text { (min.) } & \overbrace{37^{\circ}}^{\text {Temperature }} \\ 0+ & 3.3 \times 10^{6} & 1.3 \times 10^{6} & 4.8 \times 10^{5} \\ 2 & 5.6 \times 10^{6} & 1.0 \times 10^{6} & 1.8 \times 10^{5} \\ 4 & 4.3 \times 10^{6} & 8.5 \times 10^{5} & 1.5 \times 10^{4} \\ 6 & 2.9 \times 10^{6} & 1.3 \times 10^{5} & 1.1 \times 10^{4} \\ 8 & 2.4 \times 10^{6} & 2 \cdot 0 \times 10^{5} & 6.0 \times 10^{3} \\ 10 & 2.6 \times 10^{6} & 2 \cdot 1 \times 10^{5} & 2.5 \times 10^{3}\end{array}$

\section{Nocardiophage propagation}

From the results of the preceding experiments, it was evident that several factors affected the phage to host interaction. When host age before infection was examined, it was found (Table 7) that young cultures gave the best yields of phage. However, the time at which the phage + host mixture (Table 8) was sampled also determined phage yield. In a $3 \mathrm{hr}$ period, the phage output was directly related to the size of the phage inoculum. With an $18 \mathrm{hr}$ incubation time, the final phage yields were practically identical regardless of the multiplicity of infection. Upon varying the amount of the host (Table 9), an increased yield was observed with an increase of host. These data indicate that a maximum yield of phage was dependent upon the absolute number of host organisms, the growth stage of the host, and ratio of phage to host.

Under standard conditions, with young host cultures, the growth curves of phages $\phi \mathrm{C}$ and $\phi \mathrm{EC}$ were distinct from each other, but typical of phage growth curves. The latent period for phage $\phi \mathrm{C}$ was about $20 \mathrm{~min}$., the increase period was $40 \mathrm{~min}$. and the burst size about 60 particles/infective centre. Phage $\phi \mathrm{EC}$ had a latent period extending to $180 \mathrm{~min}$. and the burst size was lower than that for $\phi \mathrm{C}$, approaching only 20 particles/infective centre. 


\section{Table 7. Effect of host age on production of nocardiophages $\phi C$ and $\phi E C$}

Peptone+yeast extract medium was inoculated with Nocardia canicruria to an initial population density of $5 \times 10^{7} \mathrm{cells} / \mathrm{ml}$. At intervals, phage was added to a final concentration of $2 \times 10^{6}$ p.f.u. $/ \mathrm{ml}$. and the mixture incubated for $12 \mathrm{hr}$. After incubation, the cultures were centrifuged and the supernatant fluid assayed for plaque numbers.

\begin{tabular}{clcc} 
Phage & \multicolumn{1}{c}{ Host } & $\begin{array}{c}\text { Time before } \\
\text { phage added }\end{array}$ & Titre \\
$\phi \mathrm{C}$ & (hr) & $6.0 \times 10^{8}$ \\
& N. canicruria & 0 & $1 \cdot 5 \times 10^{9}$ \\
& N. canicruria & 3 & $2 \cdot 2 \times 10^{8}$ \\
N. canicruria & 5 & $<1 \times 10^{7}$ \\
N. canicruria & 12 & $1 \cdot 0 \times 10^{9}$ \\
& N. canicruria & 0 & $2.0 \times 10^{9}$ \\
& N. canicruria & 3 & $<1 \times 10^{7}$ \\
& N. canicruria & 12 & $7 \cdot 1 \times 10^{7}$ \\
& N. erythropolis & 0 & $<1 \times 10^{8}$ \\
& N. erythropolis & 3 &
\end{tabular}

Table 8. Effect of size of nocardiophage $\phi C$ inoculum on yield

A 2 l. flask containing $500 \mathrm{ml}$. of peptone + yeast extract $+0.01 \mathrm{M}-\mathrm{Ca}\left(\mathrm{NO}_{3}\right)_{2}$ broth was inoculated with $10 \mathrm{ml}$. of an $18 \mathrm{hr}$. culture of Nocardia canicruria. The host was incubated for $2 \mathrm{hr}$ before phage $\phi \mathrm{C}$ was added at the indicated concentrations. After incubation for 3 or $18 \mathrm{hr}$ the cultures were assayed for plaque numbers.

\begin{tabular}{|c|c|c|}
\hline \multirow{2}{*}{$\begin{array}{l}\text { Phage } \\
\text { inoculum } \\
\text { size } \\
\text { (p.f.u./ml.) }\end{array}$} & \multicolumn{2}{|c|}{ Output of phage at } \\
\hline & $3 \mathrm{hr}$ & $18 \mathrm{hr}$ \\
\hline $10^{8}$ & $5 \times 10^{9}$ & $3 \times 10^{9}$ \\
\hline $10^{2}$ & $3 \times 10^{9}$ & $5 \times 10^{9}$ \\
\hline $10^{6}$ & $3 \times 10^{8}$ & $9 \times 10^{9}$ \\
\hline $10^{5}$ & $2 \times 10^{7}$ & $9 \times 10^{9}$ \\
\hline $10^{4}$ & $4 \times 10^{6}$ & $1.8 \times 10^{10}$ \\
\hline $10^{3}$ & $3 \times 10^{5}$ & $1.6 \times 10^{10}$ \\
\hline $10^{2}$ & $1 \times 10^{5}$ & $1 \cdot 1 \times 10^{10}$ \\
\hline $10^{1}$ & $1 \times 10^{5}$ & $1 \cdot 1 \times 10^{10}$ \\
\hline
\end{tabular}

Table 9. Effect of size of the host inoculum on proliferation of nocardiophage $\phi C$

Nocardia canicruria was incubated for $2 \mathrm{hr}$ at $30^{\circ}$, harvested and suspended in fresh medium to various concentrations. After $1 \mathrm{hr}$ incubation at $30^{\circ}$, phage $\phi \mathrm{C}$ was added and the mixture incubated for $200 \mathrm{~min}$. at $30^{\circ}$.

Plaque-forming units $/ \mathrm{ml}$.

$\begin{array}{ccc}\text { Amount of host } & \begin{array}{c}\text { Phage input } \\ 3.2 \times 10^{2} \\ \text { yield (p.f.u./ml.) }\end{array} \\ \text { colony count/ml. } & \begin{array}{c}\text { Phage input } \\ 3.2 \times 10^{4}\end{array} \\ 4.3 \times 10^{7} & \begin{array}{c}6.7 \times 10^{5} \\ 2.4 \times 10^{4}\end{array} \\ 4.3 \times 10^{6} & \begin{array}{c}7.8 \times 10^{2} \\ 4.3 \times 10^{5}\end{array} & \begin{array}{c}5.2 \times 10^{7} \\ 4.3 \times 10^{4}\end{array} \\ 2.1 \times 10^{2} & 1.2 \times 10^{5} \\ & & \end{array}$


By the method of group and single additions or omissions, a chemically defined propagation medium was devised (Table 10). For maximum production of phage $\phi \mathbf{C}$, a medium composed of glycerol, nicotinamide, basal salts and three amino acids was most effective. The omission of any one of these supplements or groups of supplements (e.g. vitamins) resulted in lowered production of phage. The omission of glycerol, which resulted in a somewhat smaller production of phage, was the least necessary of the defined medium constituents.

Table 10. Simplified medium for the propagation of nocardiophage $\phi \mathrm{C}$ in Nocardia canicruria

\begin{tabular}{|c|c|c|}
\hline Supplement & Concentration & $\begin{array}{r}\text { Phage yield } \\
\text { (p.f.u./ml.) }\end{array}$ \\
\hline $\begin{array}{l}\text { Salts* } \\
\text { Vitamins } \dagger\end{array}$ & $\begin{array}{l}1 \mathrm{ml} . / 11 \mathrm{ml} . \\
0.1 \mathrm{ml} . / 11 \mathrm{ml} .\end{array}$ & $3.6 \times 10^{8}$ \\
\hline $\begin{array}{l}\text { Peptone } \\
\text { Yeast extract }\end{array}$ & $\begin{array}{l}5 \mathrm{mg} . / \mathrm{ml} \text {. } \\
3 \mathrm{mg} . / \mathrm{ml} .\end{array}$ & $1.2 \times 10^{10}$ \\
\hline Casamino acids & $1 \mathrm{mg} . / \mathrm{ml}$. & $3.6 \times 10^{8}$ \\
\hline $\begin{array}{l}\text { Casamino acids } \\
\text { Salts }\end{array}$ & $\begin{array}{l}1 \mathrm{mg} . / \mathrm{ml} . \\
1 \mathrm{ml} . / 11 \mathrm{ml} .\end{array}$ & $1 \cdot 3 \times 10^{9}$ \\
\hline $\begin{array}{l}\text { Casamino acids } \\
\text { Salts } \\
\text { Vitamins }\end{array}$ & $\begin{array}{l}1 \mathrm{mg} . / \mathrm{ml} . \\
1 \mathrm{ml} . / 12 \mathrm{ml} . \\
0 \cdot 1 \mathrm{ml} . / 12 \mathrm{ml} .\end{array}$ & $1.0 \times 10^{10}$ \\
\hline $\begin{array}{l}\text { Amino acids } \ddagger \\
\text { Salts } \\
\text { Vitamins }\end{array}$ & $\begin{array}{l}1 \mathrm{ml} . / 12 \mathrm{ml} . \\
1 \mathrm{ml} . / 12 \mathrm{ml} . \\
0.1 \mathrm{ml} . / 12 \mathrm{ml} .\end{array}$ & $8 \cdot 1 \times 10^{9}$ \\
\hline $\begin{array}{l}\text { Valine } \\
\text { Salts } \\
\text { Vitamins }\end{array}$ & $\begin{array}{l}1 \mathrm{ml} . / 12 \mathrm{ml} . \\
1 \mathrm{ml} . / 12 \mathrm{ml} . \\
0.1 \mathrm{ml} . / 12 \mathrm{ml} .\end{array}$ & $3 \cdot 1 \times 10^{9}$ \\
\hline $\begin{array}{l}\text { Isoleucine } \\
\text { Salts } \\
\text { Vitamins }\end{array}$ & $\begin{array}{l}1 \mathrm{ml} . / 12 \mathrm{ml} . \\
1 \mathrm{ml} . / 12 \mathrm{ml} . \\
0.1 \mathrm{ml} . / 12 \mathrm{ml} \text {. }\end{array}$ & $3 \cdot 1 \times 10^{9}$ \\
\hline $\begin{array}{l}\text { Leucine } \\
\text { Salts } \\
\text { Vitamins }\end{array}$ & $\begin{array}{l}1 \mathrm{ml} . / 12 \mathrm{ml} . \\
1 \mathrm{ml} . / 12 \mathrm{ml} . \\
0.1 \mathrm{ml} . / 12 \mathrm{ml} .\end{array}$ & $2 \cdot 0 \times 10^{9}$ \\
\hline $\begin{array}{l}\text { Nicotinamide } \\
\text { Salts } \\
\text { Amino acids }\end{array}$ & $\begin{array}{l}0.1 \mathrm{ml} . / 12 \mathrm{ml} . \\
1 \mathrm{ml} . / 12 \mathrm{ml} . \\
1 \mathrm{ml} . / 12 \mathrm{ml} .\end{array}$ & $2 \cdot 2 \times 10^{10}$ \\
\hline $\begin{array}{l}\text { Glycerol } \\
\text { Nicotinamide } \\
\text { Salts } \\
\text { Amino acids }\end{array}$ & $\begin{array}{l}0.1 \mathrm{ml} . / 12 \mathrm{ml} . \\
0.1 \mathrm{ml} . / 12 \mathrm{ml} . \\
1 \mathrm{ml} . / 12 \mathrm{ml} . \\
1 \mathrm{ml} . / 12 \mathrm{ml} .\end{array}$ & $7.0 \times 10^{10}$ \\
\hline
\end{tabular}

* The salt solution consisted of $\mathrm{KNO}_{3}, 1 \mathrm{~g} . ; \mathrm{K}_{2} \mathrm{HPO}_{4}, 1 \mathrm{~g} . ; \mathrm{MgSO}_{4}, 0.5 \mathrm{~g}$.; distilled water, $100 \mathrm{ml}$. $\dagger$ The vitamins consisted of $0.1 \mathrm{~g}$. each of thiamine, pyridoxine, nicotinic acid and riboflavin; distilled water, $20 \mathrm{ml}$.

$\ddagger$ The amino acids consisted of $0.1 \mathrm{~g}$. each of isoleucine, leucine and valine; distilled water, $20 \mathrm{ml}$.

\section{Host range}

Nocardiophage $\phi \mathrm{C}$ attacked two strains of Nocardia canicruria and an organism designated $N$. corallina strain $\mathrm{N} 305$. Phage $\phi \mathrm{C}$ was unable to lyse any other of the strains tested (Table 11). N. canicruria, N. erythropolis, $N$. opaca and $N$. corallina strain $\mathrm{N} 305$ were lysed by phage $\phi \mathrm{EC}$; other nocardias tested were not susceptible to 
the action of this phage. Thus the range of increasing lytic capability extends from phage $\phi \mathrm{C}$ to $\phi \mathrm{EC}$ to $\mathrm{MJP} 1$.

\section{Morphology of nocardiophages $\phi C$ and $\phi E C$}

Negatively stained phage $\phi \mathrm{C}$ was found to have a head $52 \pm 2 \mathrm{~m} \mu$ in diameter and tail $10 \mathrm{~m} \mu$ wide $\times 192 \pm 8 \mathrm{~m} \mu$ long (Pl. 1, A). The head size of phage $\phi \mathrm{EC}(\mathrm{Pl} .1, \mathrm{~B})$ was $52 \mathrm{~m} \mu$ in diameter and the tail $10 \mathrm{~m} \mu$ wide $\times 197 \mathrm{~m} \mu$ long.

\section{Table 11. Host ranges of nocardiophages $\phi C, \phi E C$ and $M J P 1$}

Stock PY preparations of the phages, containg $c a .1 \times 10^{9}$ p.f.u. $/ \mathrm{ml}$., were diluted for three ten-fold serial dilutions. $0.1 \mathrm{ml}$. samples of the dilutions were added to ca. $5 \times 10^{7}$ host cells $/ \mathrm{ml}$. contained in $2.5 \mathrm{ml}$. soft overlay agar at $45^{\circ}$. The phage-host mixtures were poured on the surface of PY agar plates. The production of plaques after $24 \mathrm{hr}$. incubation for any dilution tested was considered as a positive result.

\begin{tabular}{lccc}
\multicolumn{1}{c}{ Organism and strain } & $\phi \mathrm{C}$ & $\phi \mathrm{EC}$ & $\mathrm{MJP} 1$ \\
$N$ Nocardia canicruria 1574 & + & + & + \\
$N$. canicruria 57 & + & + & + \\
$N$. corallina 2747 & - & - & - \\
$N$. corallina w 5 & - & - & - \\
$N$. corallina 107 & - & - & - \\
$N$. corallina & - & - & $\mathrm{nt}$ \\
$N$. corallina w 3408 & - & - & $\mathrm{nt}$ \\
$N$. corallina 78 & - & - & - \\
$N$. corallina s5 & - & - & - \\
$N$. corallina N 305 & + & + & + \\
$N$. brasiliensis 301 & - & - & + \\
$N$. opaca 76 & - & - & - \\
$N$. opaca $765 \mathrm{~A}$ & - & + & $\mathrm{nt}$ \\
$N$. erthropolis & - & + & + \\
$N$. farcinica & - & - & $\mathrm{nt}$ \\
$N$. rubra 1 & - & - & - \\
$N$. rubra 74 & - & - & - \\
$N$. asteroides 58 & - & - & $\mathrm{nt}$ \\
$N$. asteroides 133 & - & - & $\mathrm{nt}$ \\
$N$. asteroides 300 & - & - & $\mathrm{nt}$ \\
$N$. asteroides 162 & - & - & $\mathrm{nt}$ \\
$N$. asteroides 92 & - & - & $\mathrm{nt}$ \\
$N$. rhodnii $\mathrm{N} 6117$ & - & - & $\mathrm{nt}$ \\
$M y$ cobacterium rhodochrous 370 & - & - & - \\
$M$. rhodochrous 482 & - & - & -
\end{tabular}

nt: not tested.

\section{DISCUSSION}

Nocardiophage $\phi \mathrm{C}$ was routinely propagated to titres of $10^{10}$ p.f.u. $/ \mathrm{ml}$. in this work. Attempts to purify the phage further by centrifugation or column chromatographic separation procedures were unsuccessful; phage $\phi \mathrm{C}$ was sensitive to these processes. Inactivation under these conditions apparently resulted from damage to the long, delicate phage tail. Nocardiophage $\phi \mathrm{EC}$ is similar to $\phi \mathrm{C}$ in susceptibility to chemical and physical agents; but $\phi \mathrm{EC}$ is easily concentrated by centrifugation without loss of titre.

Unlike phage $\phi \mathrm{EC}$ and other actinophages, phage $\phi \mathrm{C}$ attached efficiently to its host. The observed attachment was irreversible and dependent upon time and 
temperature. Attachment proceeded best in a nutrient medium; phages $\phi \mathrm{C}$ and $\phi \mathrm{EC}$ both proliferated in a peptone + yeast extract broth medium containing $0.001 \mathrm{M}$ $\mathrm{Ca}\left(\mathrm{NO}_{3}\right)_{2}$. These results suggest that either organic cofactors or host metabolism are required for attachment. The composition of the defined medium for phage $\phi \mathrm{C}$ propagation indicated that proliferation was not solely a question of host nutrition because the host, Nocardia canicruria, is easily grown in a simple defined glucose + basal salts medium (Adams, 1964). Nocardiophage $\phi \mathrm{EC}$ also resembles other actinophages more closely than does $\phi \mathrm{C}$ with respect to their latent periods.

Host populations which had been incubated for more than about $5 \mathrm{hr}$ before infection with phage $\phi \mathrm{C}$ or $\phi \mathrm{EC}$ gave low yields of phage. These results may be correlated with the developmental cycles of the host (Adams \& McClung, 1962; Adams, 1964). The interval from 0 to $5 \mathrm{hr}$ appears to represent the lag and germination phase of Nocardia canicruria. From the present work, it appears that the host is most susceptible to viral infection of these phages $\phi \mathrm{C}$ and $\phi \mathrm{EC}$ during this period. With further growth after incubation for $5 \mathrm{hr}$, a well-defined coenocytic development stage of the nocardias was noted. Multiple attachment of phage particles to the filaments may account for the decrease in nocardiophage proliferation. Unfortunately, unlike the Eubacteriales, synchronous growth of the actinomycetes in general has not been successfully achieved; only under conditions of synchronous growth of the host organisms will the more subtle of the nocardiophage + host interactions be easily explored.

This work was supported by a contract NONR 710 (36) between the Office of Naval Research and the University of Minnesota; and USPHS grant GM 12008-02 from the National Institutes of General Medical Sciences and GB 1976 from the National Science Foundation. The senior author is a USPHS Trainee supported by USPHS Training Grant 5 T 1 AI 232-03 to the University of South Dakota. We are pleased to acknowledge the capable assistance of Mrs Karen Chausee in much of the preliminary work.

\section{REFERENCES}

Adams, J. N. (1964). Recombination between Nocardia erythropolis and Nocardia canicruria. J. Bact. 88,815 .

Adams, J. N. \& McClung, N. M. (1962). Comparison of the developmental cycles of some members of the genus Nocardia. J. Bact. 84, 206.

ANDERson, D. L. \& BRADLeY, S. G. (1961). Susceptibility of Nocardiae and Mycobacteria to Actinophage. Antimicrobial Agents and Chemotherapy, pp. 894-903. Am. Soc. Microbiol., Detroit, Mich.

BISSET, K. A. \& MOORE, F. W. (1950). Jensenia a new genus of the Actinomycetales. J. gen. Microbiol. $7,89$.

Bradley, S. G., Papermaster, B. W., Watson, D. W. \& Good, R. A. (1961). Immune response to actinophage in the mouse. Proc. Soc. exp. Biol. Med. 108, 79.

Dettori, R., Maccacaro, G. A. \& Piccinin, G. L. (1961). Sex-specific bacteriophages of Escherichia coli $\mathrm{K} 12$. G. Microbiol. 9, 141.

Jones, L. A. \& BRADley, S. G. (1962). Relationship of Streptoverticillium and Jensenia to other actinomycetes. Devs ind. Microbiol. 3, 257.

LOEB, T. (1960). The isolation of a bacteriophage specific for the $\mathrm{F}^{+}$and $\mathrm{Hfr}$ mating types of $E$. coli K12. Science 131, 932.

Painter, B. G. \& Bradley, S. G. (1965). Electron microscopic observations on actinophages for Streptomyces venezuelae. J. Bact. 89, 240.

Electron micrographs of nocardiophages $\phi \mathrm{C}(\mathrm{A})$ and $\phi \mathrm{EC}(\mathrm{B})$. The marker bars denote $250 \mathrm{~m} \mu$. 

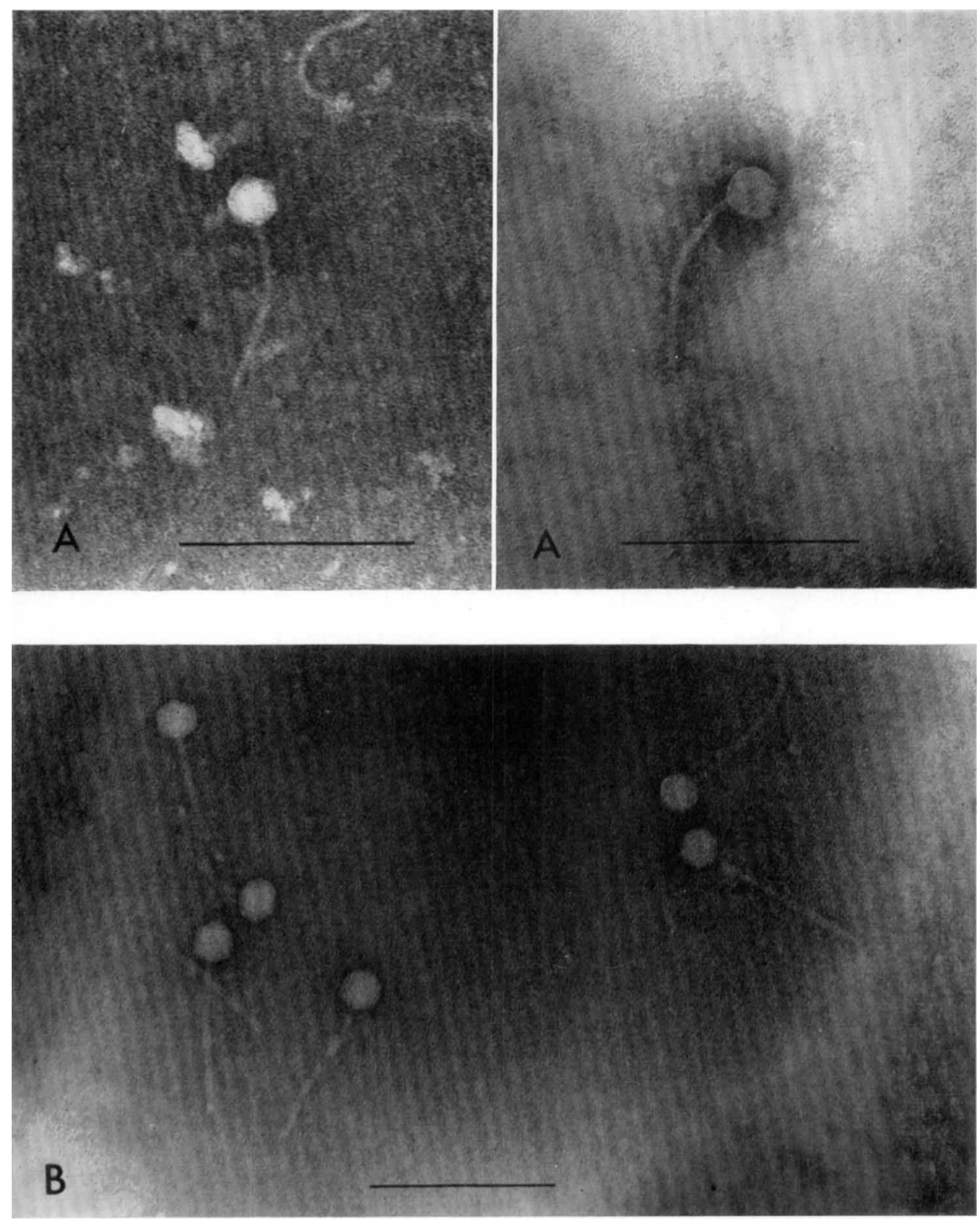